\title{
Roseovarius crassostreae sp. nov., a member of the Roseobacter clade and the apparent cause of juvenile oyster disease (JOD) in cultured Eastern oysters
}

\author{
Katherine J. Boettcher, ${ }^{1}$ Kara K. Geaghan, ${ }^{1}$ Aaron P. Maloy ${ }^{1}$ \\ and Bruce J. Barber ${ }^{2} \dagger$ \\ Departments of Biochemistry, Microbiology and Molecular Biology ${ }^{1}$ and School of Marine \\ Sciences ${ }^{2}$, University of Maine, Orono, ME 04469, USA
}

Correspondence Katherine J. Boettcher boettche@maine.edu

\begin{abstract}
An $\alpha$-proteobacterium has been identified which is believed to be the causative agent of juvenile oyster disease (JOD). Since its first isolation in 1997, the bacterium has been recovered as the numerically dominant species from JOD-affected animals throughout the north-eastern United States (Maine, New York and Massachusetts). Colonies are usually beige to pinkish-beige, although the majority of isolates recovered in 2003 from an epizootic in Martha's Vineyard, Massachusetts, produce colonies with a greenish-yellow appearance. The cells are Gram-negative, aerobic, strictly marine and rod or ovoid in appearance. They are actively motile by one or two flagella, but cells are also observed to produce tufts of polar fimbriae. The principal fatty acid in whole cells is $\mathrm{C}_{18: 1} \omega 7 \mathrm{c}$ and other characteristic fatty acids are $\mathrm{C}_{16: 0}, \mathrm{C}_{10: 0} 3-\mathrm{OH}, 11$-methyl

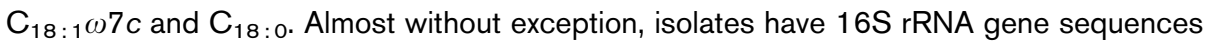
that are $100 \%$ identical to each other. Phylogenetic analyses place the organism within the Roseobacter clade of the $\alpha$-Proteobacteria, with moderate bootstrap support for inclusion in the genus Roseovarius. DNA-DNA relatedness values from pairwise comparisons of this organism with the type species of the genus (Roseovarius tolerans) and the only other described species in this genus, Roseovarius nubinhibens, were 11 and $47 \%$, respectively. Phenotypic and biochemical dissimilarities also support the assignment of this bacterium to a novel species. The name Roseovarius crassostreae sp. nov. is proposed, with the type strain

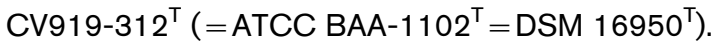

Juvenile oyster disease (JOD) causes seasonal mortalities among hatchery-produced juvenile Crassostrea virginica raised in the north-eastern United States. Single-season crop losses may exceed $90 \%$ of total production at enzootic sites in Maine, Massachusetts and New York (Bricelj et al.,

Published online ahead of print on 1 March 2005 as DOI 10.1099/ ijs.0.63620-0.

tPresent address: Eckerd College, Galbraith Marine Science Laboratory, St Petersburg, FL 33711, USA.

Abbreviations: Bchl a, bacteriochlorophyll a; JOD, juvenile oyster disease.

The GenBank/EMBL/DDBJ accession number for the 16S rRNA gene sequence of Roseovarius crassostreae sp. nov. CV919-312 ${ }^{\top}$ is AF114484.

A table detailing the fatty acid profiles for isolates of Roseovarius crassostreae sp. nov. and Roseovarius tolerans EL-172 ${ }^{\top}$ and a figure showing the relationships between isolates derived from fatty acid analysis are available as supplementary material in IJSEM Online.
1992; Davis \& Barber, 1994; Ford \& Borrero, 2001), although management strategies utilizing selected lines and early deployment of hatchery-produced seed have helped to minimize the impact (Barber et al., 1996; Barber et al., 1998; Davis \& Barber, 1999).

In 1997, a study to elucidate the aetiology of JOD led to the isolation of a marine $\alpha$-proteobacterium in the Roseobacter clade that was numerically dominant in affected animals (Boettcher et al., 1999). Additional studies revealed the consistent association of this species with JOD-epizootics in Maine and mortalities were reproduced by laboratory challenge with the representative isolate CV919-312 (Boettcher et al., 2000). Animals experiencing JODmortality in New York and Massachusetts were heavily colonized by isolates sharing 99.8-100\% $16 \mathrm{~S}$ rRNA gene sequence identity with the Maine isolates. In 2004, colonization was confirmed in a population of oysters during the week immediately preceding JOD-onset (A. P. Maloy and K. J. Boettcher, unpublished). 
Typically, mortality episodes last only a few weeks and occur coincident with, or shortly after, the onset of external signs (e.g. uneven valve margins, emaciation and conchiolin deposition on the inner shell surfaces) (Barber et al., 1996; Boettcher et al., 1999). The exact cause of death is unknown, but the feeding impairment observed in experimentally infected animals (Boettcher et al., 2000) is consistent with the 'starved' appearance of naturally affected animals. The role of toxins and/or other virulence factors has yet to be elucidated.

All known strains were obtained from cultured Crassostrea virginica. Following aseptic dissection, moistened swabs were used to collect material from the soft tissue, mantle and inner shell surfaces. The swabs were then vortexed in $1 \mathrm{ml}$ filter-sterilized sea water (FSSW). Serial dilutions of the suspensions were then plated onto sea water-tryptone (SWT) agar (containing $70 \%$ sea water, $0.5 \%$ tryptone, $0.3 \%$ yeast extract and $0.3 \%$ glycerol solidified with $1.5 \%$ agar; Boettcher \& Ruby, 1990) and incubated at $22-24^{\circ} \mathrm{C}$. The isolates used in this study are listed in Table 1 and include representatives from JOD epizootics in Maine during 1997, 1998 and 2000-2003. Also included are isolates from JOD-affected animals obtained from New York in 2002 and 2003 and from Massachusetts in 2003. Type strains of Roseobacter denitrificans, Roseobacter litoralis, Roseovarius tolerans and Roseovarius nubinhibens served as controls in some experiments.

As described previously (Boettcher et al., 1999), young colonies of the JOD-associated $\alpha$-proteobacterium appear uniformly round, non-mucoid and semi-translucent. Colonies also have a characteristic umbonate shape, a somewhat chalky consistency and leave a noticeable impression when removed from the surface of an agar plate. Isolates from JOD epizootics in Martha's Vineyard during 2003 and 2004 were found to share $100 \% 16 \mathrm{~S}$ rRNA gene sequence identity with the other isolates, but were unusual in that the resulting colonies had a greenish-yellow appearance and were slightly smaller than normal (only about $0.5 \mathrm{~mm}$ after 5 days). Typically, colonies are approximately $1.0 \mathrm{~mm}$ in diameter and have a cell-associated pinkish-beige pigmentation after approximately 5 days of growth on SWT.

The pink pigment is not, however, attributable to

Table 1. Source and growth characteristics of Roseovarius crassostreae sp. nov. used in this study

\begin{tabular}{|c|c|c|c|c|c|c|c|c|c|}
\hline \multirow[t]{2}{*}{ Isolate } & \multirow[t]{2}{*}{ Year } & \multirow[t]{2}{*}{ State $^{*}$} & \multicolumn{3}{|c|}{ Growth at $\mathrm{NaCl}(\%) \dagger$} & \multicolumn{3}{|c|}{ Growth at temperature $\left({ }^{\circ} \mathrm{C}\right)$} & \multirow[t]{2}{*}{ Reference } \\
\hline & & & Opt. & Min. & Max. & Opt. & Min. & Max. & \\
\hline CV919-312 ${ }^{\mathrm{T}}$ & 1997 & ME & $1 \cdot 5$ & $1 \cdot 0$ & $8 \cdot 0$ & 34 & 19 & 40 & Boettcher et al. (1999) \\
\hline CV1010-352 & 1997 & $\mathrm{ME}$ & $2 \cdot 0$ & $1 \cdot 0$ & $7 \cdot 5$ & 34 & 19 & 40 & Boettcher et al. (1999) \\
\hline CV923-115 & 1998 & ME & $1 \cdot 5$ & $1 \cdot 0$ & $7 \cdot 0$ & 28 & 19 & 40 & Boettcher et al. (2000) \\
\hline CV910-103 & 1998 & $\mathrm{ME}$ & $1 \cdot 0$ & $1 \cdot 0$ & $6 \cdot 0$ & 34 & 19 & 40 & Boettcher et al. (2000) \\
\hline CV1123-045 & 1998 & ME & $2 \cdot 0$ & $1 \cdot 0$ & $7 \cdot 0$ & 34 & 19 & 40 & Boettcher et al. (2000) \\
\hline CV930-004 & 1998 & $\mathrm{ME}$ & $2 \cdot 0$ & $1 \cdot 0$ & $6 \cdot 5$ & 34 & 19 & 40 & This study \\
\hline DC008 & 2000 & ME & $1 \cdot 0$ & $0 \cdot 5$ & $6 \cdot 0$ & 34 & 10 & 40 & This study \\
\hline DC010 & 2000 & $\mathrm{ME}$ & $2 \cdot 0$ & $1 \cdot 0$ & $4 \cdot 5$ & 31 & 19 & 40 & This study \\
\hline MB003 & 2000 & ME & $1 \cdot 5$ & $1 \cdot 0$ & $7 \cdot 0$ & 31 & 10 & 40 & This study \\
\hline MB004 & 2000 & $\mathrm{ME}$ & $1 \cdot 5$ & $1 \cdot 0$ & $4 \cdot 0$ & 31 & 19 & 40 & This study \\
\hline NM001 & 2000 & ME & $1 \cdot 5$ & $1 \cdot 0$ & $4 \cdot 0$ & 31 & 19 & 40 & This study \\
\hline NM002 & 2000 & $\mathrm{ME}$ & $1 \cdot 5$ & $0 \cdot 5$ & $4 \cdot 5$ & 34 & 19 & 40 & This study \\
\hline SP101 & 2001 & $\mathrm{ME}$ & $1 \cdot 0$ & $0 \cdot 5$ & $7 \cdot 0$ & 34 & 13 & 40 & This study \\
\hline SP102 & 2001 & $\mathrm{ME}$ & $1 \cdot 0$ & $0 \cdot 5$ & $7 \cdot 0$ & 34 & 13 & 40 & This study \\
\hline OB702-1 & 2002 & NY & $1 \cdot 0$ & $1 \cdot 0$ & $5 \cdot 0$ & 34 & 13 & 40 & This study \\
\hline OB802-1 & 2002 & NY & $1 \cdot 0$ & $0 \cdot 5$ & $5 \cdot 0$ & 34 & 13 & 40 & This study \\
\hline OB802-2 & 2002 & NY & $1 \cdot 0$ & $0 \cdot 5$ & $6 \cdot 0$ & 34 & 22 & 40 & This study \\
\hline MSF1002-11 & 2002 & ME & $2 \cdot 0$ & $0 \cdot 5$ & $4 \cdot 5$ & 34 & 10 & 40 & This study \\
\hline DR1003-23 & 2003 & ME & $2 \cdot 0$ & $1 \cdot 0$ & $4 \cdot 5$ & 34 & 16 & 40 & This study \\
\hline OB803-6 & 2003 & NY & $1 \cdot 5$ & $0 \cdot 5$ & $7 \cdot 0$ & 34 & 13 & 40 & This study \\
\hline MTN1003-19 & 2003 & NY & $1 \cdot 5$ & $0 \cdot 5$ & $6 \cdot 5$ & 34 & 13 & 40 & This study \\
\hline KB903-1 & 2003 & MA & $2 \cdot 0$ & $1 \cdot 0$ & $5 \cdot 0$ & 34 & 19 & 43 & This study \\
\hline EGP903-25 & 2003 & MA & $1 \cdot 5$ & $1 \cdot 0$ & $5 \cdot 0$ & 34 & 13 & 40 & This study \\
\hline CCB1003-40 & 2003 & MA & $1 \cdot 5$ & $0 \cdot 5$ & $6 \cdot 5$ & 34 & 22 & 40 & This study \\
\hline CCBE1103-8 & 2003 & MA & $2 \cdot 0$ & $1 \cdot 0$ & $8 \cdot 0$ & 34 & 22 & 40 & This study \\
\hline BS1103-19 & 2003 & MA & $2 \cdot 0$ & $1 \cdot 0$ & $5 \cdot 0$ & 34 & 19 & 43 & This study \\
\hline
\end{tabular}

*Abbreviations: MA, Massachusetts; ME, Maine; NY, New York.

$\dagger$ Medium also contained $0 \cdot 5 \%$ tryptone, $0 \cdot 3 \%$ yeast extract and $0 \cdot 3 \%$ glycerol. 
bacteriochlorophyll $a(\mathrm{Bchl} a)$ production. Cells grown in the dark did not produce an absorbance peak in the range of 790-805 nm while such absorbance peaks were observed with preparations of Roseobacter denitrificans and Roseobacter litoralis (known producers of Bchl $a$; Shiba, 1991). Still, because Bchl $a$ is variably produced in the type species of this genus (Roseovarius tolerans), we used PCR to try to detect a pufM gene (which encodes the $M$ subunit of the bacterial photosynthetic reaction centre). On the basis of pufM sequence data in GenBank, we modified the primer sets (designed for the purple phototrophs) by Achenbach et al. (2001), so that they would specifically target members of the Roseobacter clade. Each $50 \mu \mathrm{l}$ PCR contained $750 \mathrm{nM}$ each of primer pufM 568F, 5'-CGCACCTTGACTGGAC-3' (modified from pufM primer 557F of Achenbach et al., 2001) and primer pufM 698R, 5' -RTRGCGGGTCACCGCCAGAA-3' (modified from pufM primer 750R of Achenbach et al., 2001), $200 \mu \mathrm{M}$ each deoxynucleoside triphosphate, $2 \mathrm{mM} \mathrm{MgCl} 2,100-200 \mathrm{ng}$ genomic DNA and 1.25 U Taq DNA polymerase (Invitrogen) in the manufacturersupplied buffer diluted to $1 \times$ concentration. The thermocycler was set to the following conditions: $3 \mathrm{~min}$ of denaturing $\left(95^{\circ} \mathrm{C}\right)$, followed by 35 cycles of $30 \mathrm{~s}$ denaturing $\left(95^{\circ} \mathrm{C}\right), 30 \mathrm{~s}$ of annealing $\left(53^{\circ} \mathrm{C}\right)$ and $45 \mathrm{~s}$ of elongation $\left(72{ }^{\circ} \mathrm{C}\right)$, followed by an additional $5 \mathrm{~min}$ of elongation at the end of the program. The products were purified using a Centricon-100 microconcentrator (Amicon) and analysed by electrophoresis on a $1.5 \%$ agarose gel. A specific $146 \mathrm{bp}$ product (verified by sequencing) was amplified from DNAs prepared from Roseobacter denitrificans and Roseovarius tolerans (both known Bchl $a$ producers). Conversely, this product was not amplified from CV919-312 ${ }^{\mathrm{T}}$ or from Roseovarius nubinhibens (which does not produce detectable Bchl $a$; González et al., 2003).

In wet mount preparations, cells of the species appear rod to ovoid shaped and are actively motile. Bacterial suspensions were also settled onto specimen grids, stained with $1 \%$ phosphotungstinate and viewed with a Phillips CM-10 transmission electron microscope. Cells were photographed and determined to be $1 \cdot 1-4.8 \mu \mathrm{m}$ in length (mean was $2 \cdot 8 \pm 1 \cdot 2 \mu \mathrm{m}$ ) and $0.6-1 \cdot 2 \mu \mathrm{m}$ in width (mean was $0 \cdot 9 \pm 0 \cdot 2 \mu \mathrm{m})$. In addition, the majority of cells were observed to possess one or two flagella at either lateral, polar or subpolar positions (Fig. 1a-c). However, occasionally cells were observed with a single polar fimbriae tuft (Fig. 1c, d). In one instance it appeared that both a fimbriae tuft and a flagellum were present at the same pole of a single cell (Fig. 1a). It is reasonable to suspect that these structures are important for colonization of and/or persistence with the oyster host. Indeed, when the inner shell surfaces of some JOD-affected animals were viewed by scanning electron microscopy, numerous bacterial cells were present and many were clearly attached at their poles (C. L. Boardman and K. J. Boettcher, unpublished).

As previously reported, the cells are aerobic, nonfermentative, oxidase and catalase-positive (Boettcher et al., 1999). Semi-quantitative analysis of some additional enzymes from the strains in Table 1 was accomplished using API ZYM and API-20 NE tests (bioMérieux). Biolog GN2 Microplates (Biolog) were used to screen for carbon source utilization. All other biochemical tests were performed according to standard methods (Smibert \& Krieg, 1994). Although there was minor qualitative variation observed among the isolates using the API tests, all produced high levels of esterase (C4), esterase lipase (C8), acid and alkaline phosphatases and leucine arylamidase. Weak lipase and valine arylamidase activities were also uniformly produced. No cysteine arylamidase, trypsin, $\alpha$-chymotrypsin, naphthol-AS-BI-phosphohydrolase, $\alpha$ galactosidase, $\beta$-galactosidase, $\beta$-glucuronidase, $\alpha$ glucosidase, $\beta$-glucosidase, $N$-acetyl- $\beta$-glucosaminidase, $\alpha$-mannosidase, $\alpha$-fucosidase, arginine dihydrolase, urease, gelatinase or aesculinase activity was detected from any isolate. All isolates exhibited denitrifying activity in nitrate broths containing Durham tubes and, of the 95 substrates present in a Biolog GN2 Microplate, utilization of only glycerol and $\beta$-hydroxybutyrate was detected.

The effect of salinity on growth was tested in media containing $0.5 \%$ tryptone, $0.3 \%$ yeast extract, $0.3 \%$ glycerol and $\mathrm{NaCl}$ at final concentrations of $0,0 \cdot 5,1 \cdot 0$, $1 \cdot 5,2 \cdot 0,2 \cdot 5,3 \cdot 0$ and $3 \cdot 5 \%$. Cultures were prepared by diluting an overnight SWT-grown culture to an optical density (OD) of 0.02 (at $600 \mathrm{~nm}$ ) in $5 \mathrm{ml}$ of each growth medium. The cultures were then grown with shaking (200 r.p.m.) and the OD was measured at defined intervals (every 60-90 min). Optimal growth of CV919-312 ${ }^{\mathrm{T}}$ was observed at salinities of $1 \cdot 0-1 \cdot 5 \%$ and identical concentrations of potassium salts could not be substituted. The effects of temperature and $\mathrm{pH}$ were similarly determined, but in SWT broth at temperatures ranging from $4-40^{\circ} \mathrm{C}$ and in SWT broth adjusted with $\mathrm{HCl}$ or $\mathrm{NaOH}$ to $\mathrm{pH}$ values between $5 \cdot 5$ and $9 \cdot 0$. Inocula were prepared from overnight cultures as described above and growth was measured by monitoring the OD at $600 \mathrm{~nm}$. Optimal growth of CV919$312^{\mathrm{T}}$ occurred at $34-37^{\circ} \mathrm{C}$ and at $\mathrm{pH}$ values between $6 \cdot 5$ and $8 \cdot 0$. No growth was observed at either 4 or $42^{\circ} \mathrm{C}$ or at $\mathrm{pH}$ values below $6 \cdot 0$. While the requirement for sodium ions suggests that this is a strictly marine organism, the relatively low $\mathrm{NaCl}$ and high temperature optima are indicative of adaptation to coastal regions. Interestingly, significant variation was observed among the isolates with respect to their temperature and salinity optima, but there were no observable trends with respect to the year or location of isolation (Table 1).

The dominant fatty acids in whole cells of 12 representative isolates (CV919-312 ${ }^{\mathrm{T}}$, CV1010-352, CV923-115, CV910-115, CV1123-045, CV930-004, DC008, DC010, MB003, MB004, NM001 and NM002) were determined by fatty acid methyl ester (FAME) analysis at Microbial ID. The principal fatty acid in whole cells was determined to be $\mathrm{C}_{18: 1} \omega 7 c$ (mean was $85 \cdot 2 \pm 1 \cdot 7 \%$ ) and other characteristic fatty acids were $\mathrm{C}_{16: 0}(3 \cdot 6 \pm 0 \cdot 9 \%), \mathrm{C}_{10: 0} 3-\mathrm{OH}$ 
(a)
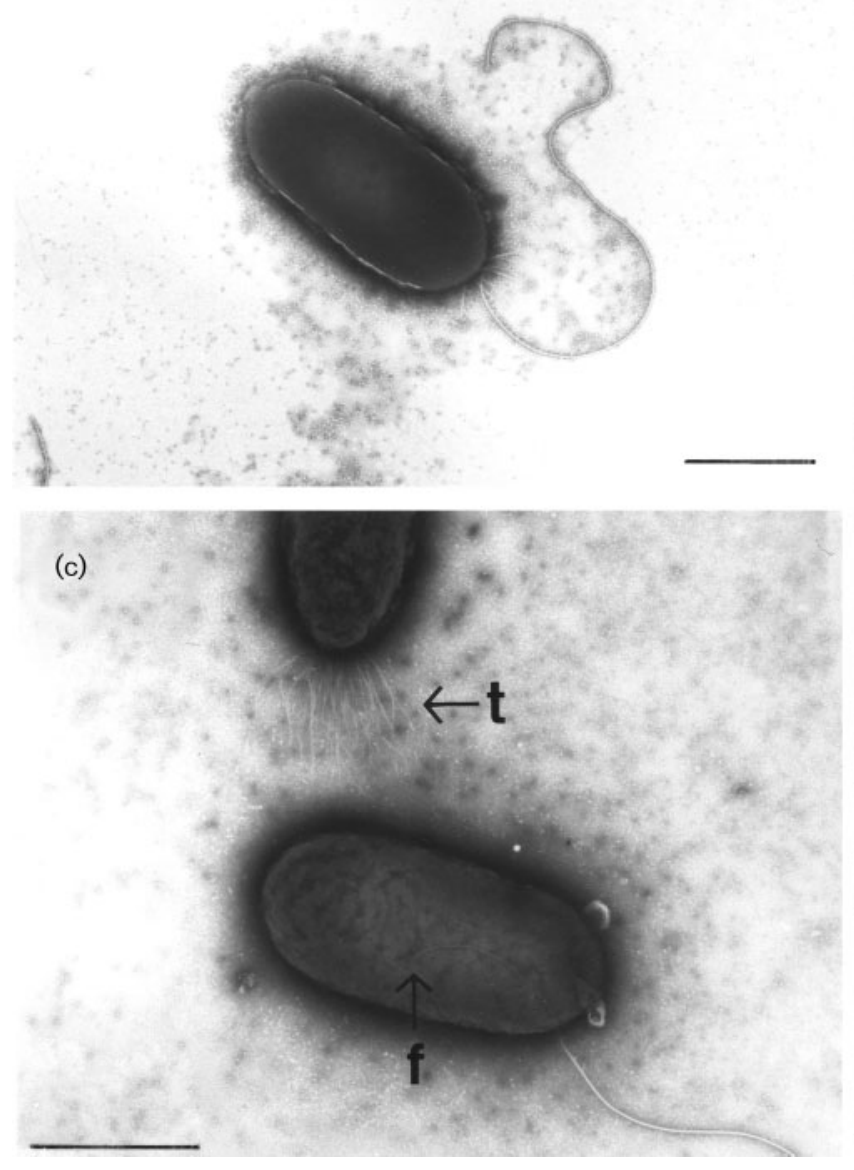
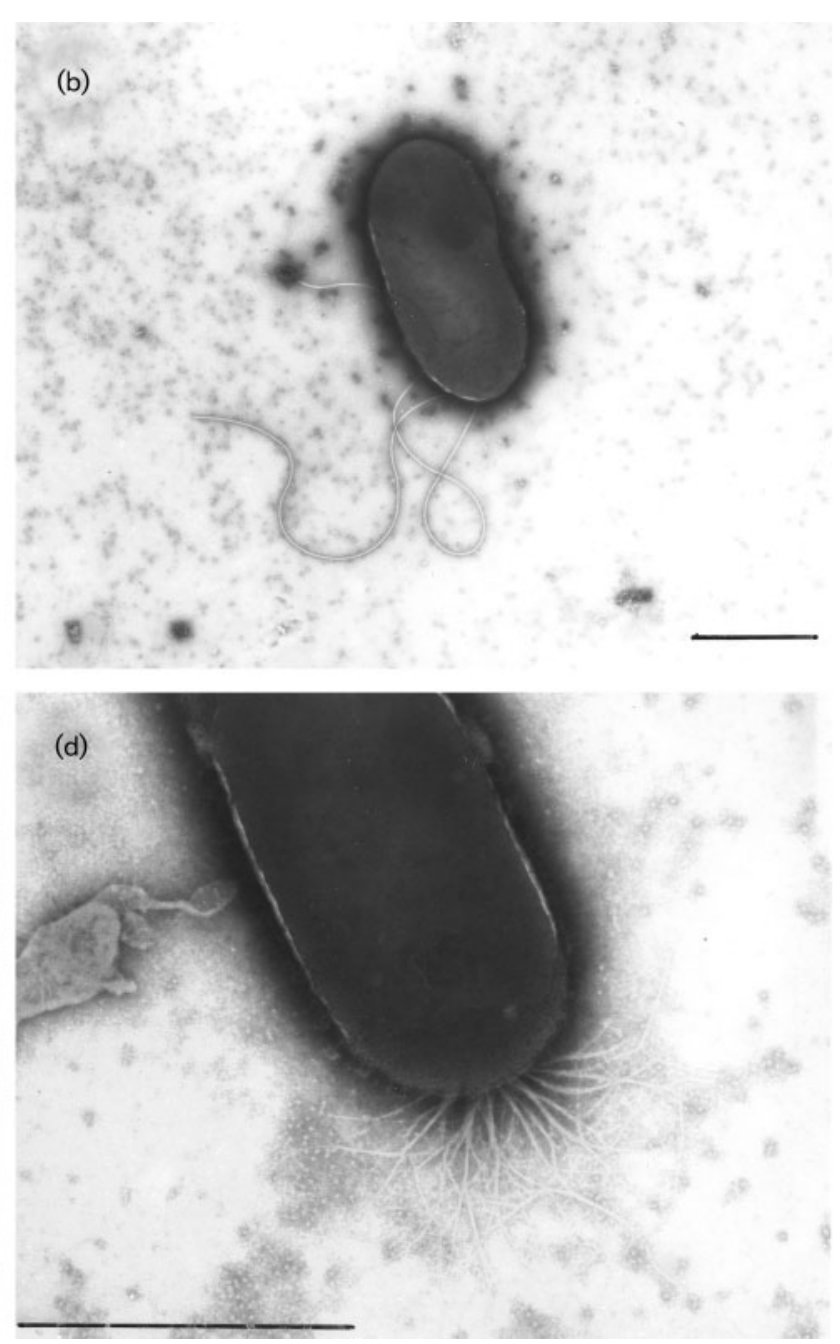

Fig. 1. Electron micrographs of Roseovarius crassostreae sp. nov. isolates. (a) Cell which appears to have a single polar flagellum and the remains of a polar 'tuft' at the same pole. (b) Cell with two subpolar flagella. (c) Two cells; one with a lateral flagellum (insertion point indicated by ' $f$ ') and one displaying a polar fimbriae 'tuft' (indicated by ' $t$ '). (d) Partial cell showing detail of polar fimbriae. Bars, $1 \mu \mathrm{m}$.

$(2 \cdot 1 \pm 0 \cdot 3 \%), 11-$ methyl $\mathrm{C}_{18: 1} \omega 7 c(0 \cdot 8 \pm 0 \cdot 2 \%)$ and $\mathrm{C}_{18: 0}$ $(0 \cdot 7 \pm 0 \cdot 3 \%)$. As no species with a similar profile was identified in the database, the fatty acid profile of the type species of the genus (Roseovarius tolerans, similarly grown on SWT agar) was obtained for comparison. A supplementary table with the complete fatty acid profiles of all analysed strains is available in IJSEM Online. The resulting dendrogram based on cluster analysis suggests that the 12 isolates form two (or three) strain groups. All are clearly distinct from Roseovarius tolerans, yet among themselves would be considered members of the same species (Euclidean distance $<4$ ). A supplementary figure is available in IJSEM Online. This assumption was verified by pairwise comparisons using DNA-DNA hybridization conducted at the Deutsche Sammlung von Mikroorganismen (DSMZ), Braunschweig, Germany. The methods of De Ley et al. (1970) and Huß et al. (1983) were employed with the following results: CV919-312 ${ }^{\mathrm{T}}$ and CV1123-045, $102 \%$; CV919-312 ${ }^{\mathrm{T}}$ and NM002, $99 \%$ and CV1123-045 and NM002, $93 \%$.

The DNA base composition of CV919-312 ${ }^{\mathrm{T}}$ was determined (by HPLC at DSMZ) to be $59 \cdot 0 \mathrm{~mol} \% \mathrm{G}+\mathrm{C}$. Comparisons of the $\mathrm{G}+\mathrm{C}$ content and other phenotypic traits of this bacterium with closely related $\alpha$-proteobacteria (as determined by $16 \mathrm{~S}$ rRNA gene sequence analysis, see below) are given in Table 2.

Regardless of the location or year of the epizootics, all isolates share $99 \cdot 8-100 \% 16 \mathrm{~S}$ rRNA gene sequence identity with the type strain CV919-312 ${ }^{\mathrm{T}}$ (Boettcher et al., 2000 and this study) (GenBank accession no. AF114484). Of described species, the highest nucleotide similarity was to Roseovarius nubinhibens $(96.1 \%$ identity). To more precisely define the relationship of the JOD-associated 
Table 2. Comparison of Roseovarius crassostreae CV919-312 ${ }^{\top}$ with the type species of the genus and related $\alpha$-proteobacteria

Strains: 1, Roseovarius crassostreae CV919-312 ${ }^{\mathrm{T}}$ (data from this study); 2, Roseovarius tolerans EL-172 ${ }^{\mathrm{T}}$ (Labrenz et al., 1999);


gallaeciensis $\mathrm{BS}_{107^{\mathrm{T}}}$ (Ruiz-Ponte et al., 1998); 6, Roseobacter litoralis ATCC $49566^{\mathrm{T}}$ (Shiba, 1991); 7, Ruegeria algicola ATCC $51440^{\mathrm{T}}$ (Lafay et al., 1995); 8, Ruegeria atlantica IAM $14463^{\mathrm{T}}$ (Rüger \& Hölfe, 1992); 9, Ruegeria gelatinovorans IAM 12617 ${ }^{\mathrm{T}}$ (Rüger \& Hölfe, 1992); 10, Sagittula stellata IAM12621 ${ }^{\mathrm{T}}$ (González et al., 1997). Ruegeria algicola, Ruegeria atlantica and Ruegeria gelatinovorans were assigned to the genus Ruegeria according to Uchino et al. (1998). All strains are catalase-positive with a strict requirement for sodium ions. + , Positive reaction; -, negative reaction; $\mathrm{ND}$, not determined or not reported.

\begin{tabular}{|c|c|c|c|c|c|c|c|c|c|c|}
\hline Characteristic & 1 & 2 & 3 & 4 & 5 & 6 & 7 & 8 & 9 & 10 \\
\hline Cell shape & Rod to ovoid & Rod & Rod & Rod & Ovoid rod & $\begin{array}{l}\text { Rod to } \\
\text { ovoid }\end{array}$ & Ovoid & $\begin{array}{c}\text { Rod to } \\
\text { ovoid }\end{array}$ & $\begin{array}{l}\text { Rod to } \\
\text { ovoid }\end{array}$ & Rod \\
\hline Pigment & Pink-beige $^{\star}$ & Brown-yellow & None & Brown & $\begin{array}{l}\text { Pink to } \\
\text { red }\end{array}$ & Red & Beige & Beige & Beige & Cream \\
\hline Fimbriae & Polar tuft & $\mathrm{ND}$ & $\mathrm{ND}$ & $\mathrm{ND}$ & $\mathrm{ND}$ & ND & ND & $\mathrm{ND}$ & $\mathrm{ND}$ & + \\
\hline Bchl $a$ & - & + & - & - & - & + & - & $\mathrm{ND}$ & ND & - \\
\hline $\mathrm{NO}_{3}^{-}$reduced to $\mathrm{NO}_{2}^{-}$ & + & - & + & - & - & - & - & + & + & - \\
\hline $\mathrm{NO}_{2}^{-}$reduced to gas & + & - & - & - & - & - & - & + & - & ND \\
\hline Aesculinase & - & $\mathrm{ND}$ & ND & ND & ND & $\mathrm{ND}$ & + & ND & $\mathrm{ND}$ & ND \\
\hline$\beta$-Galactosidase & - & ND & ND & $\mathrm{ND}$ & ND & ND & + & ND & $\mathrm{ND}$ & ND \\
\hline Gelatinase & - & - & + & ND & - & + & + & - & + & - \\
\hline $\mathrm{G}+\mathrm{C}$ content $(\mathrm{mol} \%)$ & $59 \cdot 0$ & $63 \cdot 3-63 \cdot 4$ & $62 \cdot 6-62 \cdot 8$ & $60 \cdot 5$ & $57 \cdot 6-58 \cdot 0$ & $56 \cdot 3-58 \cdot 1$ & $64 末$ & $54-57$ & 59 & 65 \\
\hline
\end{tabular}

*Some strains of this species will produce colonies with a greenish-yellow appearance.

$\dagger$ Flagella observed in preparations, but not attached to cells.

$¥$ Data from Labrenz et al. (1998).

bacterium to this and other members of the $\alpha$ proteobacteria, the sequence was manually aligned with those of 23 representative taxa using the Genetic Data Environment 2.2 Macintosh Edition. These data were imported into PAUP ${ }^{\star}$.0b10 (Sinauer Associates) and phylogenetic analyses were based on a total of 1359 characters. Distance analyses consistently placed the organism into the genus Roseovarius as shown in Fig. 2. Trees with overall similar topology were also achieved using distance and parsimony analyses; however, these analyses did not provide strong support for inclusion of this organism in any of the described genera. DNA-DNA hybridization (conducted by DSMZ) with that of the genus type species (Roseovarius tolerans) was $11 \%$ and was $47 \%$ with Roseovarius nubinhibens DNA. Thus, despite the low relatedness to Roseovarius tolerans, the organism appears sufficiently similar to Roseovarius nubinhibens such that it may be placed in the same genus. In conclusion, the phenotypic and phylogenetic analyses support placement of this bacterium as a novel species in the genus Roseovarius. The proposed name is Roseovarius crassostreae sp. nov.

\section{Description of Roseovarius crassostreae sp. nov.}

Roseovarius crassostreae (crass.o.stre' ae. N.L. n. Crassostrea systematic name of an oyster genus; N.L. gen. n. crassostreae of Crassostrea).

Aerobic, Gram-negative, ovoid to rod-shaped cells. Young colonies are small, uniformly round and have a characteristic umbonate shape. Older colonies exhibit a pinkish-beige pigmentation or, rarely, have a greenish-yellow appearance. Oxidase- and catalase-positive. Utilizes a limited range of substrates for growth, but grows well on sea water-based complex medium. Strict requirement for sodium ions. Actively motile and one to several polar, subpolar or lateral flagella may be present. Non-flagellated cells have been observed to have a single polar fimbriae tuft. Esterase (C4), esterase lipase (C8), acid and alkaline phosphatases and leucine arylamidase are produced. Weak lipase and valine arylamidase activities are also detected. Nitrate is reduced to gas. Does not produce Bchl $a$. The principal fatty acid in 


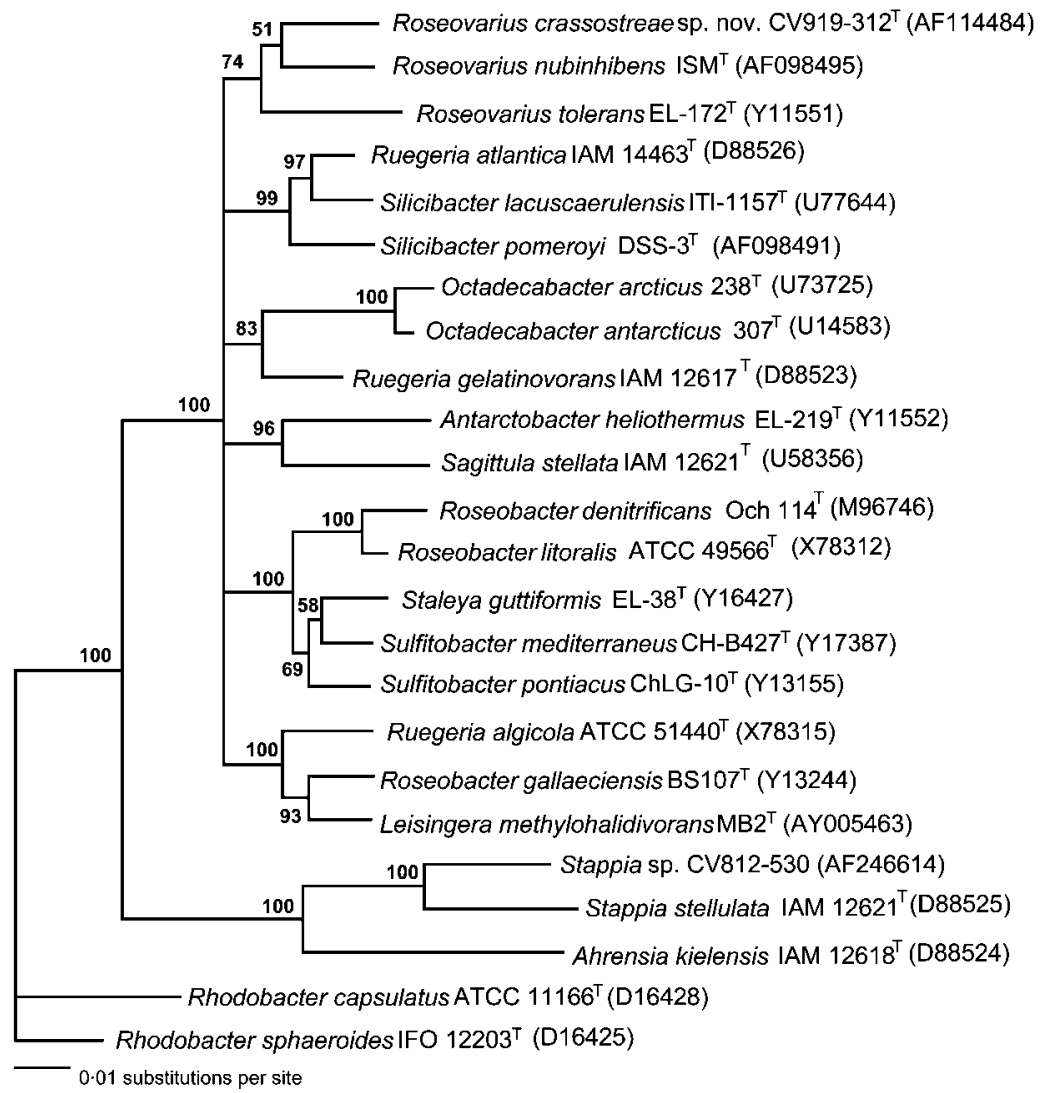

Fig. 2. Phylogenetic position of Roseovarius crassostreae within the Roseobacter clade of the $\alpha$-Proteobacteria. Two Rhodobacter species served as the outgroup and the position of a benign oyster symbiont (Stappia sp. CV812-530) is also shown. The unrooted tree was derived from distance analysis of 1359 characters in the 16S rRNA gene sequences (Escherichia coli positions 46-1448) and excluded positions with missing data and regions of uncertain alignment. The neighbour-joining method was used with 100 bootstrap replicates and a $50 \%$ majority consensus rule. Numbers indicate bootstrap values. Bar, 0.01 JukesCantor substitutions per nucleotide.

whole cells is $\mathrm{C}_{18: 1} \omega 7 c$. Other characteristic fatty acids are $\mathrm{C}_{10: 0} 3-\mathrm{OH}, \mathrm{C}_{16: 0}, \mathrm{C}_{18: 0}$ and 11-methyl $\mathrm{C}_{18: 1} \omega 7 c$. Optimal growth is observed at $34^{\circ} \mathrm{C}$, at salinities of $1 \cdot 0-1 \cdot 5 \%$ and at $\mathrm{pH}$ values between 6.5 and 8.0 . The $\mathrm{G}+\mathrm{C}$ content is $59 \cdot 0 \mathrm{~mol} \%$.

The type strain is CV919-312 ${ }^{\mathrm{T}}\left(=\right.$ ATCC BAA- $1102^{\mathrm{T}}=$ DSM $16950^{\mathrm{T}}$ ). This and all other strains of the species were isolated from Crassostrea virginica, in which it is believed to be the sole aetiological agent of JOD.

\section{Acknowledgements}

This paper is publication 2787 of the Maine Agricultural and Forest Experiment Station. M. A. Moran generously provided the type strains of Roseovarius nubinhibens, Roseobacter denitrificans and Roseobacter litoralis. The Roseovarius tolerans type strain was a kind gift from P. Hirsch. We also thank M. A. Moran for providing the Roseovarius nubinhibens DNA used in the hybridizations. We are grateful to R. Clime, P. Horne, D. Relyea, E. J. Lewis and R. Karney for providing oyster samples. The expert technical support of P. Singer at the University of Maine's DNA Sequencing Facility and K. Edwards at the University of Maine's electron microscopy facility is also greatly appreciated. We gratefully acknowledge H. G. Trüper for advice regarding appropriate nomenclature and assistance from D. Distel with the phylogenetic analyses. This study was funded by the Maine Agricultural and Forest Experiment Station, the Maine Aquaculture Innovation Center and by a USDA/CSREES/NRI award to K. J. B. and B. J. B. (ME02000-02243).

\section{References}

Achenbach, L. A., Carey, J. \& Madigan, M. T. (2001). Photosynthetic and phylogenetic primers for detection of anoxygenic phototrophs in natural environments. Appl Environ Microbiol 67, 2922-2926.

Barber, B. J., Carnegie, R. B., Davis, C. V. \& Mook, W. (1996). Effect of timing of seed deployment on growth and mortality of oysters, Crassostrea virginica, affected by Juvenile Oyster Disease (JOD). $J$ World Aquac Soc 27, 443-448.

Barber, B. J., Davis, C. V. \& Crosby, M. A. (1998). Cultured oysters, Crassostrea virginica, genetically selected for fast growth in the Damariscotta River, Maine, are resistant to mortality caused by Juvenile Oyster Disease (JOD). J Shellfish Res 17, 1171-1175.

Boettcher, K. J. \& Ruby, E. G. (1990). Depressed light emission by symbiotic Vibrio fischeri of the sepiolid squid Euprymna scolopes. J Bacteriol 172, 3701-3706.

Boettcher, K. J., Barber, B. J. \& Singer, J. T. (1999). Use of antibacterial agents to elucidate the etiology of juvenile oyster disease (JOD) in Crassostrea virginica and numerical dominance of an $\alpha$ Proteobacterium in JOD-affected animals. Appl Environ Microbiol 65, 2534-2539.

Boettcher, K. J., Barber, B. J. \& Singer, J. T. (2000). Additional evidence that juvenile oyster disease is caused by a member of the Roseobacter group and colonization of nonaffected animals by Stappia stellulata-like strains. Appl Environ Microbiol 66, 3924-3930.

Bricelj, V. M., Ford, S. E., Borrero, F. J., Perkins, F. O., Rivara, G., Hillman, R. E., Elston, R. A. \& Chang, J. (1992). Unexplained mortalities of hatchery-reared, juvenile oysters, Crassostrea virginica (Gmelin). J Shellfish Res 11, 331-347. 
Davis, C. V. \& Barber, B. J. (1994). Size-dependent mortality in hatchery-reared populations of oysters, Crassostrea virginica, Gmelin 1791, affected by juvenile oyster disease. J Shellfish Res 13, 137-142.

Davis, C. V. \& Barber, B. J. (1999). Growth and survival of genetically selected Eastern Oysters, Crassostrea virginica (Gmelin 1791) affected by juvenile oyster disease. Aquaculture 178, 253-271.

De Ley, J., Cattoir, H. \& Reynaerts, A. (1970). The quantitative measurement of DNA hybridization from renaturation rates. Eur J Biochem 12, 133-142.

Ford, S. E. \& Borrero, F. J. (2001). Epizootiology and pathology of juvenile oyster disease in the Eastern oyster, Crassostrea virginica. J Invertebr Pathol 78, 141-154.

González, J. M., Mayer, F., Moran, M. A., Hodson, R. E. \& Whitman, W. B. (1997). Sagittula stellata gen. nov., sp. nov., a lignintransforming bacterium from a coastal environment. Int $J$ Syst Bacteriol 47, 773-780.

González, J. M., Covert, J. S., Whitman, W. B. \& 8 other authors (2003). Silicibacter pomeroyi sp. nov. and Roseovarius nubinhibens sp. nov., dimethylsulfoniopropionate-demethylating bacteria from marine environments. Int J Syst Evol Microbiol 53, 1261-1269.

Huß, V. A. R., Festl, H. \& Schleifer, K. H. (1983). Studies on the spectrophotometric determination of DNA hybridization from renaturation rates. Syst Appl Microbiol 4, 184-192.

Labrenz, M., Collins, M. D., Lawson, P. A., Tindall, B. J., Braker, G. \& Hirsch, P. (1998). Antarctobacter heliothermus gen. nov., sp. nov., a budding bacterium from hypersaline and heliothermal Ekho Lake. Int J Syst Bacteriol 48, 1363-1372.

Labrenz, M., Collins, M. D., Lawson, P. A., Tindall, B. J., Schumann, P. \& Hirsch, P. (1999). Roseovarius tolerans gen. nov., sp. nov., a budding bacterium with variable bacteriochlorophyll a production from hypersaline Ekho Lake. Int J Syst Bacteriol 49, 137-147.
Lafay, B., Ruimy, R., Rausch de Traubenberg, C., Breittmayer, V., Gauthier, M. J. \& Christen, R. (1995). Roseobacter algicola sp. nov., a new marine bacterium isolated from the phycosphere of the toxinproducing dinoflagellate Prorocentrum lima. Int J Syst Bacteriol 45, 290-296.

Rüger, H.-J. \& Hölfe, M. G. (1992). Marine star-shaped-aggregateforming bacteria: Agrobacterium atlanticum sp. nov.; Agrobacterium meteori sp. nov.; Agrobacterium ferrugineum sp. nov., nom. rev.; Agrobacterium gelatinovorum sp. nov., nom. rev.; and Agrobacterium stellulatum sp. nov., nom. rev. Int J Syst Bacteriol 42, 133-143.

Ruiz-Ponte, C., Cilia, V., Lambert, C. \& Nicolas, J. L. (1998). Roseobacter gallaeciensis sp. nov., a new marine bacterium isolated from rearings and collectors of the scallop Pecten maximus. Int J Syst Bacteriol 48, 537-542.

Schaefer, J. K., Goodwin, K. D., McDonald, I. R., Murrell, J. C. \& Oremland, R. S. (2002). Leisingera methylohalidivorans gen. nov., sp. nov., a marine methylotroph that grows on methyl bromide. Int J Syst Evol Microbiol 52, 851-859.

Shiba, T. (1991). Roseobacter litoralis gen. nov., sp. nov., and Roseobacter denitrificans sp. nov., aerobic pink-pigmented bacteria which contain bacteriochlorophyll a. Syst Appl Microbiol 14, 140-145.

Smibert, R. M. \& Krieg, N. R. (1994). Phenotypic characterization. In Methods for General and Molecular Bacteriology, pp. 607-654. Edited by P. Gerhardt, R. G. E. Murray, W. A. Wood \& N. R. Krieg. Washington, DC: American Society for Microbiology.

Uchino, Y., Hirata, A., Yokota, A. \& Sugiyama, J. (1998). Reclassification of marine Agrobacterium species: proposals of Stappia stellulata gen. nov., comb. nov., Stappia aggregata sp. nov., nom. rev., Ruegeria atlantica gen. nov., comb. nov., Ruegeria gelatinovora comb. nov., Ruegeria algicola comb. nov., and Ahrensia kieliense gen. nov., sp. nov., nom. rev. J Gen Appl Microbiol 44, 201-210. 